\title{
Quantitative investigations on the human entorhinal area: left-right asymmetry and age-related changes
}

\author{
H. Heinsen ${ }^{1}$, R. Henn ${ }^{2, *}$, W. Eisenmenger ${ }^{3}$, M. Götz ${ }^{4}$, J. Bohl ${ }^{5}$, B. Bethke ${ }^{6}$, U. Lockemann ${ }^{7}$, K. Püschel ${ }^{7}$ \\ ${ }^{1}$ Morphologische Hirnforschung, Universitäts-Nervenklinik, Füchsleinstrasse 15, D-97080 Würzburg, Germany \\ ${ }^{2}$ Institut für Gerichtliche Medizin der Universität, Müllerstrasse 44, A-6020 Innsbruck, Austria \\ ${ }^{3}$ Institut für Rechtsmedizin der Universität, Frauenlobstrasse 7a, D-80337 München, Germany \\ ${ }^{4}$ Institut für Pathologie, Klinikum Aschaffenburg, Am Hasenkopf, D-63739 Aschaffenburg, Germany \\ ${ }^{5}$ Institut für Neuropathologie der Universität, Langenbeckstrasse 1, D-55131 Mainz, Germany \\ ${ }^{6}$ Institut für Pathologie, Klinikum Bayreuth, Preuschwitzer Strasse 101, D-95445 Bayreuth, Germany \\ ${ }^{7}$ Institut für Rechtsmedizin, Butenfeld 34, D-22529 Hamburg, Germany
}

Accepted: 1 March 1994

\begin{abstract}
The total nerve cell numbers in the right and in the left human entorhinal areas have been calculated by volume estimations with the Cavalieri principle and by cell density determinations with the optical disector. Thick gallocyanin-stained serial frozen sections through the parahippocampal gyrus of 22 human subjects ( $10 \mathrm{fe}-$ male, 12 male) ranging from 18 to 86 years were analysed. The laminar composition of gallocyanin (Nissl)-stained sections could easily be compared with Braak's (1972, 1980) pigmentoarchitectonic study, and Braak's nomenclature of the entorhinal laminas was adopted. Cellsparse laminae dissecantes can more clearly be distinguished in Nissl than in aldehydefuchsin preparations. These cell-poor dissecantes, lamina dissecans externa (dis-ext), lamina dissecans 1 (dis-1) and lamina dissecans 2 (dis-2), were excluded from nerve cell number determinations. An exact delineation of the entorhinal area is indispensable for any kind of quantitative investigation. We have defined the entorhinal area by the presence of pre-alpha cell clusters and the deeper layers of lamina principalis externa (pre-beta and gamma) separated from lamina principalis interna (pri) by lamina dissecans 1 (dis-1). The human entorhinal area is quantitatively characterized by a left-sided (asymmetric) higher pre-alpha cell number and an age-related nerve cell loss in pre as well as pri layers. At variance with other CNS cortical and subcortical structures, the neuronal number of the entorhinal area appears to decrease continuously from the earliest stages analysed, although a secular trend has to be considered. The asymmetry in pre-alpha cell number is discussed in the context of higher human mental capabilities, especially language.
\end{abstract}

Key words: Human entorhinal area - Ageing - Lateralitity

\footnotetext{
* Professor Henn was killed in a traffic accident in July 1992 Correspondence to: $\mathrm{H}$. Heinsen
}

\section{Introduction}

The entorhinal region occupies the caudal parts of the lobus piriformis in lower mammals (Stephan 1975). The progressive enlargement and rostral expansion of the temporal lobes shift the entorhinal region from an occipital position in lower mammals to a rostromedial one in anthropoids (Rose 1926). The gyrus parahippocampalis of higher mammals is homologous to the caudal part of the lobus piriformis in lower mammals. The term regio entorhinalis was coined by Brodmann (1909). "Rhinalis" can be misleading, since the entorhinal region is present in all mammals, in macrosmatic, microsmatic as well as anosmatic species (Stephan 1975). A number of authors have grouped the entorhinal region into periarchicortical structures, since the entorhinal region represents an important interface between reciprocal neocortical hippocampal (archicortical) structures (van Hoesen et al. 1975; van Hoesen and Pandya 1975 a, b; van Hoesen 1982; Witter et al. 1989). This does not imply that the entorhinal region is a vestigial part of the CNS. In summarizing his quantitative and comparative anatomical data, Stephan (1975) clearly demonstrated the progressive increase of CA1, subicular, and entorhinal volumes in man. Interestingly, these archicortical and periarchicortical structures exhibit characteristic pathological changes in a variety of neurodegenerative diseases, including Alzheimer's disease (Hirano and Zimmerman 1962; McLardy 1970; Hooper and Vogel 1976; Kemper 1978; Hyman et al. 1984; Braak and Braak 1991), Parkinson's disease (Braak and Braak 1990), Pick's disease (Jakob 1979), and Huntington's chorea (Bauer et al. 1991; Braak and Braak 1992 a, b; Heinsen et al. 1992), diseases which exclusively afflict man. Cytoarchitectonic studies of schizophrenia, an additional disease confined to the human brain, point to specific circumscribed neurodevelopmental disturbances in the entorhinal region (Jakob and Beckmann 1986; Arnold et al. 1991; Beckmann and Jakob 1991). These numerous investigations on the 
pathology of the entorhinal area contrast with a paucity of quantitative studies on this important structure. According to S. Rose (1927), the surface of the human entorhinal region is larger than in all other species investigated. Falkai et al. (1988) have calculated a lower nerve cell number in the entorhinal region of schizophrenics, and in a previous study, Trillo and Gonzalo (1992) have described an age-related decrease of neuronal density in the human entorhinal area. These three studies are in part heavily biased by inaccurate delineations using topographical instead of cytoarchitectonic criteria. Therefore, we have reinvestigated this area using Braak's (1972, 1980) subdivisions and applying a combination of effective stereological tools, including Cavalieri's principle for volume and the optical disector (Gundersen 1986; Pakkenberg et al. 1989; Regeur and Pakkenberg 1989; Braendgaard et al. 1990; West and Gundersen 1990; West $1993 \mathrm{a}, \mathrm{b}$ ) for nerve cell density estimations in frontal serial Nissl-stained sections through the human entorhinal area.

\section{Materials and methods}

Altogether 26 male and female brains, ranging from 18 to 86 years, were obtained in accordance with the laws of the Federal Republics of Germany and Austria. Both hemispheres were fixed for at least 3 months (Stephan 1960; Bauchot 1967) in 4\% formalin, pretreated in ascending concentrations of glycerol-DMSO-formalin mixtures, embedded in gelatine, and soaked again in glycerol-DMSO-formalin mixtures. After these cryoprotective procedures (Rosene et al. 1986), the embedded hemispheres were deep-frozen in isopentane at $-60^{\circ} \mathrm{C}$ and serially sectioned on a Tetrander (Jung, Nussloch) at 600 to $700 \mu \mathrm{m}$. The slices were alternatingly collected in three plastic boxes and stored in $4 \%$ formalin. For routine as well as quantitative examinations, each third section from the fronto-parallel series was Nissl stained with gallocyanin. One set of serial sections was alternatingly stained with gallocyanin and aldehydefuchsin. Details of the staining and mounting procedures are given elsewhere (Braak 1980; Heinsen and Heinsen 1991). Initially, 26 agematched and sex-matched individuals without known psychiatric or neurological diseases were selected for this kind of quantitative analysis. Four brains had to be excluded because of diffuse gliosis in cortical and subcortical temporal lobe structures. A reinvestigation of small paraffin-embedded tissue samples (Heinsen and Heinsen 1991) from the afflicted regions revealed perivascular edema, perivascular myelin loss in gyral medullary rays, unspecific increase of perivascular lymphoid cells, and macrophages. These neuropathological changes were sequels to local or systemic disturbances in the blood-brain barrier (Fig. 6). Cases with senile changes (presence of Alzheimer's neurofibrillary tangles, senile or amyloid plaques) were likewise excluded from the study (Heinsen et al. 1990).

The volume of an irregular serially-cut three-dimensional object, can be easily determined if the area (A) of the profile(s), the thickness $(t)$, and, unless each section is quantified, the interval $k$ (three in our study because we stained every third section) of sections analysed are known.

The combined areas of the molecular layer, the pre-alpha cell layer and the lamina dissecans externa, the pre-beta through gamma, the laminae dissecantes externa and interna, and the pri-alpha through gamma layer were estimated by point counting (Weibel 1979) at $\times 7.5$ magnification (Olympus SZH stereo microscope, $\times$ 10 widefield eyepieces, $10 \times 10 \mathrm{~mm}$ ocular grid subdivided into $20 \times 20$ lines). The area of the pre-alpha layer was estimated in a subsequent step at $\times 25$ magnification. Only hits falling onto prealpha cell clusters or small cell streaks connecting individual cell clusters were recorded. Therefore, the reference volume of the pre- alpha layer was confined to pre-alpha clusters, the outlines of which were sharply delineated in the optical plane. Figures $1 \mathrm{~b}$ and $2 \mathrm{~b}$ depict individual pre-alpha cells forming clusters within and those outside the optical plane. The outlines of the latter appear blurred and were excluded from point counting.

The thickness of gallocyanin stained sections was determined by means of the fine adjustment knob of an Olympus BH microscope at $\times 200$ magnification. Before determining the section thickness, the scale of the fine adjustment knob was calibrated by stacks of microscope cover slides. The stacks were put vertically onto the microscope's stage with their edges facing the microscope's $\times 10$ objective. The thickness of the stacks was measured by means of a cross eyepiece micrometer ( $\times 10$ magnification), and then two lines were drawn with a felt pen on the upper and lower side of the stacks. The line on the cover slide facing the microscope's condenser was focused at $\times 200$ magnification. The fine adjustment knob was then turned until the line on the most superficial cover slide facing the microscope's objective appeared in the optical plane. The gradation marks of the scale linearly correlated with the thickness of the stacks of cover slides over a range of 400 to $700 \mu \mathrm{m}$. One of the 200 gradation marks of the fine adjustment knob represented $0,0033 \mathrm{~mm}$. The thickness of our gallocyanin stained sections varied from 455 to $578 \mu \mathrm{m}$. The thickness of individual sections from one brain varied by about $10 \%$, but between the brains this difference could be much higher.

The working distance of conventional oil-immersion objectives falls within the range of 0.12 to $0.3 \mathrm{~mm}$. To estimate nerve cell density by the optical disector (Gundersen 1986; Pakkenberg et al. 1989; Braendgaard et al. 1990; West and Gundersen 1990; West $1993 \mathrm{a}, \mathrm{b}$ ), we focused the thick gallocyanin-stained sections with the coarse adjustment knob until the outlines of neurones in the visual field of an ocular grid appeared sharp (Zeiss, oil immersion Planapo objective $40 /$ N.A. 1.0). The ocular grid was subdivided by $10 \times 10$ lines. The combination of $\mathrm{a} \times 10$ widefield eyepiece and a $\times 40$ immersion objective yielded an area of $0.015625 \mathrm{~mm}^{2}$ to be scanned for nerve cell density. All neuronal nucleoli (or nuclei of rare small nerve cells with invisible or unidentifiable nucleoli) that appeared in the field of the ocular grid during focusing within a depth range $29.7 \mu \mathrm{m}$ were counted. To achieve a constant optical thickness in cell density estimation, rings were mounted on the fine and on the coarse adjustment knob of the microscope. Two horizontal metal pins were fixed at a distance of $2.1 \mathrm{~mm}$ from each other on the ring of the coarse adjustment knob. A third pin, fixed vertically on the ring of the fine adjustment knob could move like a pointer within the limits of the two horizontal pins of the coarse adjustment knob. The amplitude of the vertical pin was $0.0297 \mathrm{~mm}$ thus representing the depth of the optical field.

In a pilot study, we had checked the nerve cell density of all pre-alpha cell clusters from the lateral to the medial border of the entorhinal area in a 18 -year-old and a 86 -year-old subject. Nerve cell density slightly decreased in a rostrocaudal direction but remained constant in a mediolateral direction. Therefore, we confined nerve cell density counting to three pre-alpha clusters per section in a medial, intermediate, and lateral position.

A systematic random probing of cell density can be achieved by moving the mechanical stage of the microscope by constant intervals through a reference space in a vertical as well as a horizontal direction. The presence of dissecantes rendered the laminar composition of the entorhinal area highly irregular. In the pilot study we were meandering in $0.1-\mathrm{mm}$ vertical and $2-\mathrm{mm}$ horizontal steps through the entorhinal cortex and frequently hit the dissecantes or lost orientation at $\times 400$ magnification. We found nerve cell density fairly constant within individual laminas. Furthermore, the proportion of pre-beta and gamma to the pri layers remained constant. In addition, the shape of the entorhinal area, especially its mediolateral extent, was rather uniform. Therefore, we decided to confine nerve cell density determination to a total of eight radially stacked fields of the pre- and pri-layers (four in pre-beta through gamma, four in pri-alpha through gamma). These eight radially stacked optical fields per section were selected from medial, intermediate, and lateral positions in the entorhinal area. The starting position was deter- 
mined with random numbers, e.g. random number one corresponded to a medial position in the first of frontal serial sections; the nerve cell density in the ensuing section was determined in intermediate positions of the entorhinal area, then in lateral positions in the third, and again in medial positions in the fourth sections. Given the fairly constant overall thickness and ratios of/between the entorhinal layers and only slight variations in the laminar neuronal density, this methodological approach satisfies to a great degree the stringent criteria of systematic random probing.

Nerve cell density multiplied by the volume of the containing space (entorhinal laminas) yields the total number of nerve cells in pre-alpha, pre-beta-gamma, and pri-layers, irrespective of swelling or shrinkage due to histological procedures.

All data were subject to a statistical analysis at the Rechenzentrum der Universität Würzburg. A probit analysis of the data suggested logarithmic transformation of the raw data. The data were either subject to a $t$-test to test side-differences or to correlation/regression analysis with $r$ being Pearson's coefficient of the product-moment correlation ( $X=$ age in years, $Y=$ nerve cell number) to check age-dependent neuronal decline.

\section{Results}

Cytoarchitectonic delineation of the human entorhinal area

Several investigators have analysed the human entorhinal area using classical cytoarchitectonic (Rose 1927; Filimonoff 1947), combined cyto- and myeloarchitectonic (Sgonina 1937), pigmentoarchitectonic (Braak 1972), immunohistochemical (Beall and Lewis 1992), or histochemical (Hevner and Wong-Riley 1992) methods. In our experience, thick gallocyanin-stained Nissl sections could easily be compared with Braak's (1972) aldehydefuchsinstained sections (Figs. 1 a-2 b), and Braak's delineations and subdivisions could be recognized in all cases studied.

According to Rose $(1926,1927)$, the entorhinal area represents a three-layered archicortex composed of two principal layers, the lamina principalis externa (pre) and lamina principalis interna (pri) that are covered by a superficial molecular, zonal or plexiform layer (Figs. 1 a -2 b). The two principal layers are separated from each other by a lamina dissecans (dis) (Figs. $1 \mathrm{a}-2 \mathrm{~b}$ )

Nerve cell clusters, which actually represent a threedimensional network of intensely basophilic, chiefly stellate or multipolar neurones, are a highly characteristic component of the entorhinal pre layer. These two-dimensional clusters comprise the lamina principalis externa alpha (pre-alpha; Figs. 1 a -2 b). Rostrally, the clusters fuse to form a continuous external granular (granuloid according to Sanides 1969) lamina. The pre-alpha cells continuously increase in size from rostral to caudal. Caudally, the nerve cell clusters become very conspicuous (Figs. 3-5).

The lamina dissecans represents a layer with few nerve cells that separates the external and internal principal layers (Figs. $1 \mathrm{a}-2 \mathrm{~b}$ ). In caudal planes of the entorhinal area, an additional dissecans extends laterally from the praesubiculum to the area entorhinalis transitiva. We think it necessary to distinguish between these laminas, and we designate the outer one the lamina dissecans 1 (dis-1, Figs. 3, 1 a), and the caudal inner lamina, the lamina dissecans 2 (dis-2, Fig. 2b). Both dissecantes run parallel in the caudal entorhinal fields. The lamina dissecans 1 regularly ends rostral from the lamina dissecans 2 (Figs. 4, 5, large arrows). Thus, the rostral limits of the entorhinal area are characterized by the appearance of pre-alpha cell clusters, lamina dissecans 1, and pre-beta-gamma through pri-layers (Fig. 3). Disappearance of the lamina dissecans 1 represents the caudal limit of the entorhinal area in the present study (Fig. 5), although pre-alpha cell clusters and lamina dissecans 2 could be seen for an additional $2-3 \mathrm{~mm}$ further caudal.

The lateral limits of the entorhinal area are characterized both by descending pre-alpha cells (Braak et al. 1976) and by the attenuation and disappearance of the pre-beta-gamma layers (Fig. 3, arrow between eim and etr). In younger individuals, pre-alpha cells were strongly basophilic and densely packed. The lateral entorhinal fields could unequivocally be delineated from the transentorhinal region. In individuals older than 70 years, pre-alpha cells were less basophilic, and fewer cells formed an uninterrupted descending line from the superficial pre-alpha layer to deep parts of layer III in the transentorhinal region. However, the unusually thick sections facilitated the delineation of lateral entorhinal from transentorhinal fields even in the oldest cases studied.

A number of archicortical fields border the medial parts of the entorhinal area: the cortex praepiriformis at its rostral pole; the claustrum praeamygdaleum in an intermediate position; the periamygdaleum and the socalled hippocampal-amygdaloid transition area (HATA) (Rosene and van Hoesen 1987) abut the medial and caudal fields of the gyrus ambiens; finally, the praesubiculum is continuous with the area entorhinalis marginalis caudalis at mediocaudal planes.

The oromedial area entorhinals oralis (eo) could easily be distinguished from the cortex praepiriformis (pp) due to the clustering of pre-alpha cells in the former and a continuous stratum densocellulare in the latter area (Fig. 3, Cl).

The subregio praeamygdalea of the claustrocortex praepiriformis (pra) is characterized by nerve cell clusters descending into deeper layers and running toward the claustrum praepiriforme (Fig. 3). Again, our unusually thick sections clearly facilitated the retrieval of small descending nerve cell clusters and their distinction between superficial pre-alpha cell clusters at the medial entorhinal-claustrum praepiriforme border.

There was no difficulty in delineating the fields covering the gyrus ambiens and those on the gyrus semilunatus because the area entorhinalis marginalis oralis represents a highly characteristic border region between the allocortical entorhinal area and the corticoid structures of the amygdaloid complex.

With the appearance of the sulci uncalis and hippocampalis (Duvernoy 1988), we could observe an intensely basophilic layer that was continuous with the praesubiculum. This basophilic hippocampal layer attained a superficial position in caudal planes of the gyrus ambiens (Fig. 4). The absence of pre-alpha cell clusters facilitated the distinction between the area gyri ambientis centralis and this modified hippocampal (HATA) field (Rosene and van Hoesen 1987). 

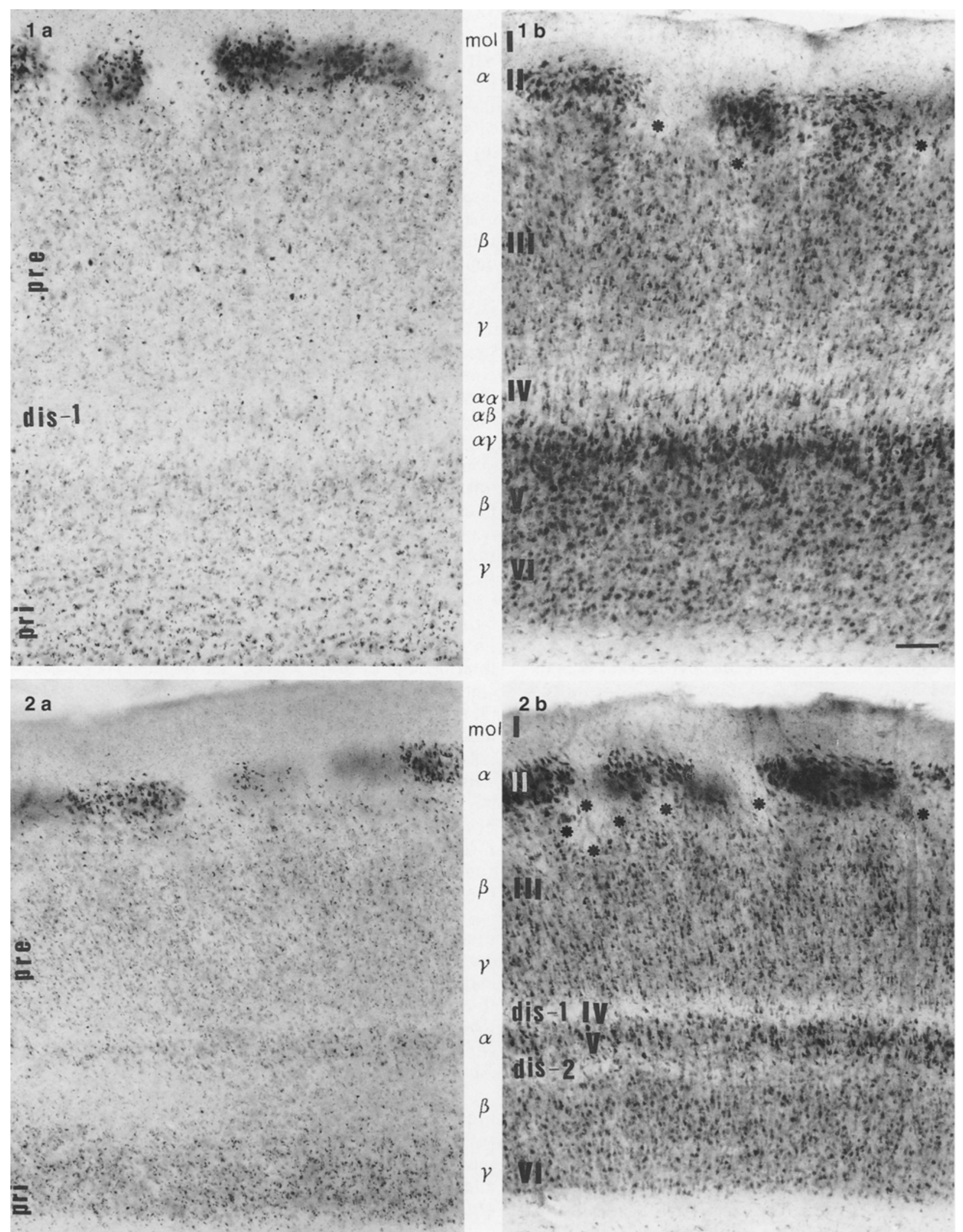

Fig. 1a-2b. Alternately aldehydefuchsin - (Figs. 1 a, 2 a) and gallocyanin - (Figs. 1 b, 2 b) stained parallel sections through the entorhinal area of a 35-year-old female subject (death by myocardial infarct). Bar in $\mathbf{1 b}$ corresponds to $0.2 \mathrm{~mm}$. Same magnification in all figures

Fig. 1a, b. Area entorhinalis centralis lateralis. In b, the lamina principalis interna alpha-alpha, a layer consisting of a stack of large pyramidal and fusiform cells $2-4$ cells wide, runs parallel to the lamina principalis interna. Pri-alpha-alpha cells are less basophilic and generally larger than pri-alpha-gamma cells. Outside the cen-

tral entorhinal fields, pri-alpha-gamma is simply designated lamina pri-alpha by Braak (1972). Asterisks indicate dis-ext (Filimonoff's Diss $^{\text {ext }}$ or Sognina's pre b)

Fig. $\mathbf{2 b}$. The area entorhinalis caudalis is characterized by the presence of two laminae dissecantes (dis-1 and dis-2). Dis-2 may correspond to the monkey's Vc (Amaral et al. 1987). Pre-beta cell columns are less well developed in the caudal entorhinal fields whereas dis-ext (asterisks) expands and can sometimes be seen in contact with dis-1 
The praesubiculum and the area entorhinalis marginalis caudalis both possess superficial nerve cell clusters. The praesubicular clusters consist of small neurones, while the entorhinal clusters are formed by large multipolar nerve cells (Fig. 4). These features rendered the delineation of both regions unequivocal.

\section{Laminar composition of the entorhinal fields}

Braak (1972) described an intricate lamination of aldehydefuchsin-stained thick frozen sections culminating in the central fields, area entorhinalis centralis medialis and lateralis. Compared with aldehydefuchsin-stained sections, parallel Nissl sections revealed some additional features of the entorhinal laminar architecture. Lamina dissecans 1 and 2 can better be perceived in Nissl preparations, and the Nissl method shows that the pre-alphabeta border undulates in a highly irregular dentate-like or columnar fashion. Pre-alpha cell clusters were separated from the tips of pre-beta cell columns by a cell-poor cleft. This cleft was small in rostral fields of the entorhinal area (Fig. 3) and continuously widened in caudal directions, separating pre-alpha from pre-beta as well as sculpturing individual pre-beta cell columns (Fig. 4). In the most caudal fields, the superficial basophilic pre-beta cell columns became less conspicuous, and large pre-alpha cell clusters were separated from deep pre-beta layers by a wide cleft. Additionally, in older individuals, an obvious loss of superficial pre-beta cells took place (Fig. 6). The cell-poor space was not mentioned by Braak (1972), but it corresponds to Sgonina's (1937) pre b and Filimonoff's (1947) Diss ${ }^{\text {ext }}$. We prefer the latter designation (dis-ext, Figs. 1 b, 2 b). There is no histologically recognizable border between superficial diss-ext and the ensuing molecular layer, and both layers contain few neurones. Therefore, in the present quantitative study both layers were analysed together.

The central entorhinal fields are characterized by the presence of a pri-alpha-alpha layer (Fig. $1 \mathrm{~b}$, alpha-alpha) consisting of a row two to four cells wide of slender pyramidal and fusiform cells with conspicuous, frequently cork-screw-like dendrites. These cells were seen in serial sections to emerge from the pri-alpha layer and were separated from the latter by the pri-alpha-beta layer (Braak 1972). The volume of the pri-alpha-alpha layer comprised less than $1 \%$ of the total pri-layer and, therefore, was quantitatively analysed together with the underlying prilayers. Neither the pre-beta-gamma nor the pri-layers were further subdivided in the quantitative analysis.

\section{Nerve cell number}

In general, the entorhinal cortex - with the exception of the molecular layer - is composed of medium-sized pyramidal, fusiform or oval cells with clearly visible nucleoli, typical stellate cells, and rare fork-like or navicular cells. Other cell types, e.g. small oval nerve cells with deeply indented nuclei and small or invisible nucleoli are far less numerous.

\section{Asymmetry of pre-alpha cell number}

The total number of pre-alpha cells exhibited a marked left-right asymmetry. In 18 out of the 22 cases analysed, the number of pre-alpha cells was higher on the left than on the right side. The asymmetry can numerically be expressed by Eidelberg and Galaburda's (1982) asymmetry index. In one 36-year-old male brain, the left pre-alpha cell number surpassed the corresponding cell number on the right entorhinal area by $51 \%$. In nine cases, this leftright difference varied between 48.9 and $21.7 \%$, and in the remaining eight cases the total pre-alpha cell number was 16.7 to $4.6 \%$ higher on the left side.

This left-right asymmetry was reversed in four cases. A maximal right-left asymmetry was encountered in a 35 -year-old female $(-32.7 \%)$ followed by a 46 -year-old female subject $(-24.6 \%)$ and a male subject (22-year-old, $-2.82 \%)$. It was negligible in an 86-year-old female brain $(-0.17 \%)$. The data were logarithmically transformed to minimize possible age-related sampling effects. Statistical analysis revealed a highly significant left-sided asymmetry in pre-alpha cell number $(t$-test $p<0.00074)$.

\section{Age-related changes in pre-alpha cell number}

The total number of pre-alpha cells was generally higher in younger than in the older individuals studied. Considerable individual differences were encountered. It was not the oldest cases analysed that showed a minimal number of pre-alpha cells, but a 65 -year-old male brain on the left as well as the right side $(59,035$ vs 50,108 pre-alpha cells, Table 1). In contrast, 95,237 pre-alpha cells were calculated in the left and 81,450 stellate cells in the right entorhinal area of a 75-year-old male brain (Table 1).

Pre-alpha cell number was negatively correlated with age (coefficient of correlation: left pre-alpha $r=-0.4411$, $P<0.040$; right pre-alpha $r=-0.4834, P<0.023$ ). The age-related decline of pre-alpha cell number is expressed by the logarithmic equations:

$$
\begin{aligned}
\mathrm{Y}\left(\mathrm{N}_{\text {left pre-alpha }}\right)= & -0.002052529 * \mathrm{X}(\text { age in years }) \\
& +5.0114 \\
\mathrm{Y}\left(\mathrm{N}_{\text {right pre-alpha }}\right)= & -0.002109192 * \mathrm{X}(\text { age in years }) \\
& +4.9324
\end{aligned}
$$

\section{Pre-beta-gamma}

Total nerve cell number and lack of asymmetry. The total number of pre-beta-gamma cells exceeded that of the prealpha neurones by a factor of about ten. In 15 out of 22 cases, the left-sided pre-beta-gamma cells outnumbered those on the corresponding right side. Maximal values of pre-beta-gamma cells with more than 1.6 million cells were encountered on the left side of a 28 -year-old male and on the right side of a 46-year-old male brain (Table 1). The total number of pre-beta-gamma cells was lowest in the right entorhinal area of a 65-year-old male and in the right entorhinal area of a 80-year-old female subject (Table 1). Extreme asymmetries were apparently ob- 

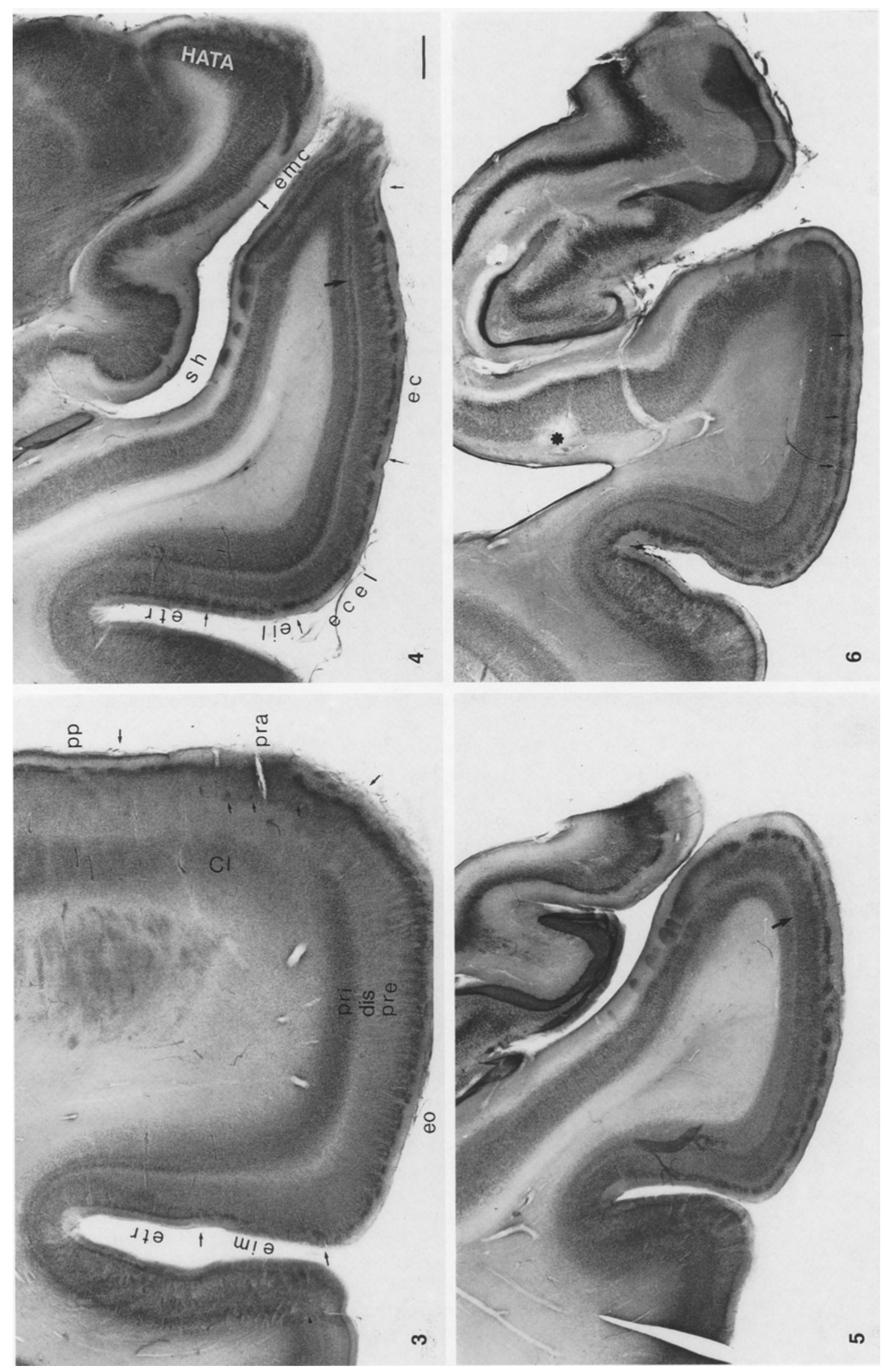
Table 1. Sex, age, neurone number (N) in entorhinal layers pre-alpha through pri, individual coefficient of error (CE), body length, mean coefficient of error, and mean biological variance over age-range

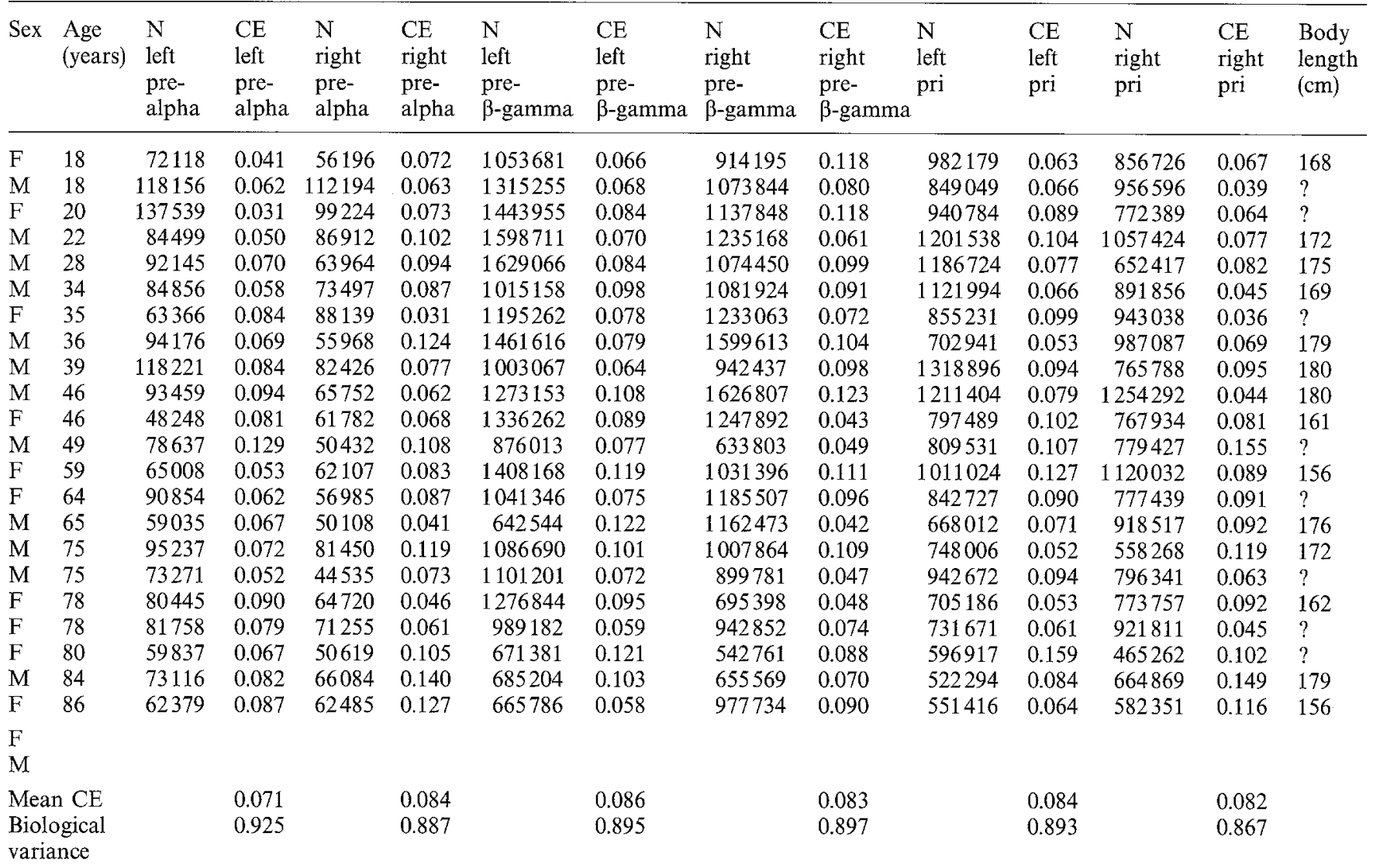

served on both sides, with $59 \%$ on the left side of a 78 year-old female and $-57.6 \%$ on the right side of a 65 year-old male, but these differences were statistically not significant $(t$-Test $P>0.16)$.

Age-related changes in pre-beta-gamma nerve cell number. Pre-beta-gamma cell number was negatively correlated with age (coefficient of correlation: left pre-beta-gamma $r=-0.6348, \quad P<0.0015 ; \quad$ right $\quad$ pre-beta-gamma $r=-0.4878, P<0.021)$. The age related decline of prealpha cell number is expressed by the logarithmic equations:

$$
\begin{aligned}
\mathrm{Y}\left(\mathrm{N}_{\text {left pre-beta-gamma }}\right)= & -0.003346098 * \mathrm{X} \text { (age in years) } \\
& +6.2080 \\
\mathrm{Y}\left(\mathrm{N}_{\text {right pre-beta-gamma }}\right)= & -0.002462083 * \mathrm{X} \text { (age in years) }
\end{aligned}
$$

Fig. 3-5. Frontal sections through the parahippocampal gyrus of a 35-year-old female subject (myocardial infarct), stained with gallocyanin. Bar in Fig. 4 corresponds to $1 \mathrm{~mm}$. Same magnification in all figures

Fig. 3. Oral limits of the entorhinal area. Short arrows point to descending nerve cell clusters in the claustrocortex praeamygdaleus. The lamina principalis externa (pre) is separated by the cell-poor lamina dissecans (dis $=$ dis-1) from the lamina principalis interna (pri). $\mathrm{Cl}$, Claustrum praeamygdaleum; eim, area entorhinalis interpolaris medials; $e o$, area entorhinalis oralis; etr, area transentorhinalis; $p p$, cortex praepiriformis; pra, claustrocortex praeamygdaleus

Fig. 4. The sulcus hippocampi (sh) separates the parahippocampal gyrus from the gyrus ambiens. The latter is covered by entorhinal pre-layers, but in the caudally ensuing section an ascending, intensely basophilic hippocampal layer replaces the entorhinal layers in the hippocampal-amygdaloid transition area $(H A T A)$. Note the emergence of dis-2 (large arrow) in the medial parts of ec, and a perforated lamina pri-alpha. ec, Area entorhinalis caudalis; ecel, area entorhinalis centralis lateralis; eil, area entorhinalis interpolaris lateralis; emc, area entorhinalis marginalis caudalis; etr, area transentorhinalis; HATA, hippocampal-amygdaloid transition area; sh, sulcus hippocampi

Fig. 5. In this plane of section, dis-1 has disappeared and dis-2 (large arrow) is continuous with a wide dissecans in the parasubiculum. This plane of section was excluded from morphometrics

Fig. 6. Section of 78-year-old female brain. This case is documented to show criteria of exclusion. The basal parts of the prosubiculum (asterisk) have been destroyed by an elective parenchymal necrosis (Scholz 1957). Dis-ext, a cell-poor space beneath pre-alpha (arrows) is extremely wide. It is not clear whether this phenomenon represents age-related nerve cell loss, or transneuronal degeneration due to vascular damage of the prosubiculum together with circulatory disturbances in the molecular layer of the fascia dentata 
Pri

Total nerve cell number and absence of asymmetry. A maximum of $1,318,896$ pri neurones was calculated in the left entorhinal area (39-year-old male subject) and minimal number of 522,294 in the left entorhinal area (84-year-old male) and 465,262 neurones in the right area entorhinalis (80-year-old female subject Table 1). Left-right asymmetries in the nerve cell number were less frequent in the lamina principalis interna. Only 12 out of 22 cases exhibited higher left nerve cell numbers, ranging between $58.1 \%$ and $3.8 \%$. On the right side, the differences were less marked, with a maximum of $-33.6 \%$ in a 36 -yearold male and $-3.5 \%$ in a 46 -year-old male brain. Statistically significant asymmetries in total pri cell numbers could not be detected $(P>0.31)$.

Age-related changes in pri nerve cell number. Pri nerve cell number was negatively correlated with age (coefficient of correlation: left pri $r=-0.6787, P<0.0005$; right pri $r=-0.4669, P<0.028)$. The age related decline of prealpha cell number is expressed by the logarithmic equations:

$$
\begin{aligned}
\mathrm{Y}\left(\mathrm{N}_{\text {left pri }}\right)= & -0.00325515^{*} \mathrm{X} \text { (age in years) } \\
& +6.09714 \\
\mathrm{Y}\left(\mathrm{N}_{\text {right pri }}\right)= & -0.002019068^{*} \mathrm{X} \text { (age in years) } \\
& +6.0122
\end{aligned}
$$

\section{Discussion}

Laminar composition, nomenclature, and exclusion of the dissecantes from quantitative estimation of total nerve cell number

The presence of an entorhinal region in lower as well as in higher mammals has been confirmed by a number of authors (for a review see Stephan 1975). Nevertheless, there is no agreement between individual authors concerning either the nomenclature of the constituent layers of the entorhinal region or its subdivision into parts, fields and subfields.

It is generally acknowledged that the entorhinal region possesses more layers than the medially neighbouring hippocampal areas. Most investigators have recognized six layers (Brodmann 1909; Zunino 1909; Lorente de Nó 1933; Krieg 1946; Vaz Ferreira 1951; Blackstad 1956; van Hoesen and Pandya 1975a; Room and Groenewegen 1986; Amaral et al. 1987; Köhler 1988; Beall and Lewis 1992; Hevner and Wong-Riley 1992; Trillo and Gonzalo 1992). Cajal (1972) found seven, and Smith and White (1964) described four. The layers were successively numerated by Roman numerals from I (plexiform, molecular or zonal layer) through VI (VII) (polymorph, substriata and limitans). Cajal (1972), Lorente de Nó (1933) and Stephan (1975) described, in addition, the major cellular components of these layers.

We prefer Braak's (1972) nomenclature that represents an amplification of Rose's $(1926,1927)$ comparative anatomical description, from reptiles through primates to man. The results of Braak's pigmentoarchitectonic studies could easily and consistently be transferred to Nissl stained sections. This classification is founded on the presence or absence of laminas instead of minutiae including cell size, shape and densities (Sgonina 1937). Furthermore, Braak (1972) could demonstrate a hitherto unrecognized pri-alpha-alpha layer in the central fields of the entorhinal area. Numeration of entorhinal laminas is equivocal. Lorente de Nó's (1933) lamina IV consists of deep pyramids, whereas Cajal (1972) designated lamina $4^{\circ}$ "couche plexiforme profonde". Van Hoesen and Pandya (1975a) characterized layer IV in area 28a of rhesus monkeys as a cell-sparse lamina dissecans or inner plexiform layer that in turn comprised major NFT-containing projection neurones (Hyman et al. 1990) in patients with Alzheimer's disease. Stephan (1975) distinguished two dissecantes, 3diss and 4diss, separated from each other by a lamina 4 or stratum magnocellulare. Amaral et al. (1987) subdivided layer V into sublayers Va to $\mathrm{Vc}$ in their investigation of the monkey entorhinal area. $\mathrm{Vc}$, a cell-free layer, is most prominent in the caudal entorhinal fields. Beall and Lewis (1992) failed to detect a lamina dissecans in their fields $E_{I}$ and $E_{C}$, although a cell-sparse cleft can clearly be recognized between layers V and VI (cf. Fig. 4 A, p 248 and Fig. 5 A, p 249). According to Witter et al. (1989), layer IV in the cat's entorhinal region is composed of large pyramidal neurones that project to the amygdala, accumbens, and the limbic cortex. Therefore, in order to avoid confusion with neocortical layers and introduction of additional terms or numerals, we estimate Braak's (1972) terminology superior to the widely but inconsistently used layer I to layer VI subdivision.

Nissl-stained thick frozen sections are superior in the demonstration of nerve-cell-poor dissecantes (Figs. 1 a-2 b). In addition to the proper lamina dissecans that separates lamina principalis externa (pre) from lamina principalis interna (Fig. 3, pri) further dissecantes have been described. In their ontogenetic studies, Beck (1940) and Filimonoff (1947) distinguished between at least two different dissecantes. Beck termed the developmentally early cell-poor streak in the cortical plate delta and the later appearing one epsilon II. Delta is highly characteristic (facultative) of the entorhinal region, and epsilon II is obligatory. It is absent in some entorhinal areas, extends into the medially adjoining praesubiculum (which corresponds to our parasubiculum), and is characteristic of the parasubicular region. Beck's delta and epsilon II are most probably equivalent to Filimonoff's Diss $^{1}$ and Diss $^{2}$, respectively. Filimonoff (1947) described an additional Diss ${ }^{\mathrm{ext}}$, "either subdividing the external layer (ext) into two sublayers or separating the external layer (ext) from the intermediate (m) layer", but he did not illustrate Diss ${ }^{\text {ext }}$. Economo (1929) mentioned a "very poorly-celled, paler horizontal band (that) separates II from III". A likely candidate for Filimonoff's Diss ${ }^{\text {ext }}$ and Economo's horizontal band could be Rose's Pre-beta (Sgonina's Pre b). This layer is cell-rich at rostral levels but cell-poor and fibre-rich in the caudal ensuing planes. In the present study, we have adopted Filomonoff's terminology of the dissecantes (Fig 2 b). 
These cell-poor layers were excluded from the estimation of nerve cell densities as well as from the calculation of the absolute nerve cell number. This procedure guaranteed a fairly exact estimation of total nerve cell numbers which is expressed in CE values lower than 0.1 (Table 1).

\section{Entorhinal borders are crucial factors in quantitative estimations}

An exact and reproducible delineation of the entorhinal fields is prerequisite for any quantitative study of this archicortex. The rostral pole coincides with Braak's (1972) area entorhinalis oralis and area gyri ambientis oralis. Usually, dis-1 extended further rostrally, but prealpha cell clusters fused to a single granuloid lamina II in the most rostral planes.

The medial borders were established by the cortex praepiriformis, Brockhaus' (1940) claustrocortex praeamygdaleus, the fields of Brockhaus' (1940) periamygdaloid regions, the so-called hippocampal-amygdaloid transitional area (HATA, Rosene and van Hoesen 1987) and, finally, by the praesubiculum. In conventional histological sections, $20-40 \mu \mathrm{m}$ thick, the transitions may appear subtle, but with our technique the delineation of adjacent fields was facilitated, because the thickness of the sections amplified slight histological differences by a factor of 20 to 30 .

The lateral parts of the entorhinal area continue into Braak's area transentorhinalis medialis (Fig. 3, etr) that is characterized by a descent of pre-alpha cells into deeper layers. This border could be unequivocally recognized in all cases studied.

We defined the caudal border of the entorhinal area by the disappearance of dis-1, which occurred within a range of less than $1 \mathrm{~mm}$ in serial frontoparallel sections. Pre-alpha cell clusters and dis- 2 could be traced further caudally for an additional 1-3 mm. Amaral et al. (1987) described an absence of layer IV in Nissl preparations, but found readily discernible fibres in myelin preparations in area $E_{C L}$ of macaque monkeys. Possibly the authors confuse dis-1 (their layer IV) with dis-2 (most probably their layer $\mathrm{Vc}$ ). Parasagittal sections through the entorhinal region are difficult to interpret because the parahippocampal gyrus is slightly c-shaped, so rostrocaudally and mediolaterally arranged fields will inevitably be cut in a complex manner in sagittally directed planes of section. Dis-1 and dis-2 can be distinguished in Figs. $1 \mathrm{c}$ and $1 \mathrm{~d}$ in the paper of Hevner and Wong-Riley (1992), the latter extending further caudally than the former. The two dissecantes cannot be identified in caudal parts of Hevner and Wong-Riley's $E_{C}$ and $E_{C L}$. It remains to be elucidated whether neocortical laminas enter the caudal entorhinal fields from TH or TF. If so, the caudal $E_{C}$ as well as $E_{C L}$ would represent transitional fields comparable to Braak's (1972) areae transentorhinales. Nevertheless, the disappearance of dis- 1 represented a fairly consistent feature in the delineation of the caudal entorhinal area (Figs. 4,5).

\section{Bias in quantitative estimations}

The introduction of the optical disector (Gundersen 1986; Pakkenberg et al. 1989; Braendgaard et al. 1990; West and Gundersen 1990, West 1993a) greatly facilitates quantitative investigations and guarantees unbiased estimations of nerve cell densities. Nevertheless, our investigation is not free from bias because we determined laminar volumes in rather thick histological sections instead of infinitely thin mathematical planes (Weibel 1979). Quantitative volume estimations in thick sections are biased by overprojection and truncation (Cruz-Orive 1983). Heavily stained layers usually project from deeper parts of the section to the surface (overprojection). On the other hand, less well-stained layers in the superficial parts of sections are not detected during point counting because of the faint staining (truncation). These factors are known to compensate for each other, but the exact degree of compensation remains unknown. In our investigations, we used a stereo microscope, and the optical plane of the three-dimensional image comprised only 40 $60 \mu \mathrm{m}$ at low-power magnification during volume estimation of pre- and pri-layers and less than $20 \mu \mathrm{m}$ at highpower magnification during pre-alpha volume estimation instead of the 500- to $600-\mu \mathrm{m}$ thickness of the frozen section. Gundersen and Jensen (1987) proposed a simple mathematical procedure to eliminate the effects of overprojection. With this factor, the nerve cell number would decrease by about $10 \%$, but since we do not know the compensatory effects of overprojection and truncation, we have not corrected our raw data.

Some Scandinavian authors have provided valuable suggestions and formulas for designing a stereological study and estimating the precision of stereological procedures in quantitative analyses of the human neocortex and allocortex (Gundersen 1986; Pakkenberg et al. 1989; Regeur and Pakkenberg 1989; West and Gundersen 1990; West 1993 a, b). The coefficient of error for the nerve cell number $\mathrm{CE}(\mathrm{N})$ (Table 1) indicates the precision of individual estimates of the total nerve cell number. The mean $\mathrm{CE}(\mathrm{N})$ in our investigation varied between 0.071 and 0.086 . It is possible to calculate the contribution of the biological variance to the observed variance of total neurone number from the data obtained. The biological variation was maximal $(92.5 \%)$ in total left pre-alpha cell number and minimal $(86.7 \%$ ) in total right pri cell number. The rostrocaudal length of the entorhinal area ranged from 13 to $25 \mathrm{~mm}$. Thus, 36 frozen serial sections $700 \mu \mathrm{m}$ thick will maximally comprise the full rostrocaudal extent of this region. Since we stained every third section, we had to estimate areas, nerve cell densities, and thickness from a minimal of six to a maximal set of twelve sections. It must be stressed that the section thickness decreases by about $20 \%$, from 700 to $540 \mu \mathrm{m}$ during the staining and mounting procedures of the frozen sections. Consequently, the section thickness cannot be directly read from the microtome and must, therefore, be determined optically in each stained section. Due to the relatively constant shape of the parahippocampal gyrus, the quantitative estimation could be confined to each third section. This is at variance with the highly irregularly 
shaped human dentate gyrus that has CEs of up to 0.163 (West and Gundersen 1990). Thus, the estimation of total entorhinal nerve cell numbers could be performed within $2-3 \mathrm{~h}$ in a sufficiently precise and reproducible manner (CE in Table 1) even in a set consisting of only six serial sections.

\section{Total nerve cell number}

To our knowledge, only one study has addressed the question of total entorhinal nerve cell number. Falkai et al. (1988) calculated total numbers of $61 \pm 18^{*} 10^{5}$ and $67 \pm 21 * 10^{5}$ pyramidal cells in the entorhinal cortex of seven male and four female subjects (mean age $42.6 \pm 19.6$ years). The author's results are two to three times higher than our estimations, and several factors may contribute to this discrepancy. In our investigation, the total volume of the entorhinal area varied between $203 \mathrm{~mm}^{3}$ (80-year-old female) to $546 \mathrm{~mm}^{3}$ (34-year-old male; not corrected for individual tissue shrinkage!), the nerve cell density between 14,631 (pre-alpha layer, 39year-old male) to 5,118 neurones per cubic millimetre (pre-beta-gamma layer, 65-year-old male). The average nerve cell density in the paper of Falkai et al. (1988) is 7,592 cells $/ \mathrm{mm}^{3}$ in males and 7,672 pyramidal cells $/ \mathrm{mm}^{3}$ in females. Therefore, the difference in both studies is mainly attributable to volume differences, because the total cell number results from the product of nerve cell densities and the volume of the containing space (entorhinal cortex). We have already criticized Falkai's (1988) delineation of the entorhinal region (Beckmann and Heinsen 1989). We think that the authors' reply (Bogerts and Falkai 1989) is unsatisfactory because Nissl and pigment preparations yielded nearly identical results in laminar and areal composition of the entorhinal region. Topographical delineations of the parahippocampal gyrus proved to be highly unreliable (Heckers et al. 1990). In addition, the area gyri ambientis oralis as well as the area entorhinalis oralis considerably preceded the appearance of the subiculum in serial frontal sections, whereas the topography of the diencephalic corpus geniculatum laterale coincided with cytoarchitectonic fields that contained superficial nerve cell clusters but no dissecantes. In human brains, the lateral border of the lateral entorhinal area is established by the area transentorhinalis medialis and never by the prepiriform cortex. This is at variance with the rat, and the delineation given by Blackstad (1956) in this species is not relevant to the human brain. Furthermore, with the exception of one case, only left hemispheres were analysed by Falkai et al. (1988). We confined estimations of nerve cell density to nerve cell-rich layers and excluded the dissecantes from total nerve cell calculation. The laminae dissecantes are not completely devoid of nerve cells, but the cell density in these dissecantes is by a factor of about ten or more lower than in the adjacent pre or pri layers. The average combined volume of the molecular layer, dis-ext, dis- 1 , and dis- 2 is about $30 \%$ of the total entorhinal volume, or amounts to $100 \mathrm{~mm}^{3}$. If we assume an average nerve cell density of 1,000 cells $/ \mathrm{mm}^{3}$ in the dissecantes, then the total entorhinal nerve cell number would increase by an additional 100,000 cells. This is insufficient to explain the differences between our results and the observations of Falkai et al. (1988).

Trillo and Gonzalo (1992) confined their investigations to measurements of nerve cell densities in layers II, III, and V of the left "lateral area of the entorhinal cortex" of 30 individuals who were $15(?)$ to $86(?)$ years old. The authors do not mention the method by which nerve cell densities were evaluated, nor could we find any indication to correct tissue shrinkage effects in their $7-\mu \mathrm{m}$ thick histological sections. The number of neurones is depicted in nine diagrams without any indication of the volumes to which these nerve cell densities refer (cubic micrometres, millimetres or centimetres). Calculation of nerve cell density without correction by individual shrinkage factors is of limited scientific value (Braendgaard and Gundersen 1986; Drüge et al. 1986; Kretschmann et al. 1986; Flood and Coleman 1987). This is corroborated by the observed tremendous age-independent variations of nerve cell densities in the present study

S. Rose (1927) found the surface of the human entorhinal region to be two and a half times as big as that of chimpanzees. Stephan (1975) regarded the human entorhinal region as a progressive structure in a phylogenetic scale. None of the authors estimated cell densities and numbers in the entorhinal region.

\section{Age-related nerve cell loss}

Transverse ageing studies on brain weight are biased by the so-called secular trend (Röthig 1974; Miller and Corsellis 1977; Kretschmann et al. 1979; Miller et al. 1980; Haug 1984, 1985). Brain weight has been shown to be correlated with body length (Spann and Dustmann 1965; Dekaban and Sadowsky 1978; Ho et al. 1980 a, b). Since young adults of the 1990s are generally taller than their great-grandparents, the decreased brain weight and probably decreased neurone number in old people results from the combined effect of smaller body size and age-related parenchymal loss. On the one hand, the results of recent investigations (Haug et al. 1983; Haug 1985) on age-related nerve cell loss differ from Brody's (1955) original and widely cited conclusions. On the other hand, Pakkenberg et al. (1989) have reported a continuous decline of neocortical nerve cell numbers with age by 50 to $100 * 10^{6}$ (?) neurones per annum (?) (age range 20 to 90 years).

Although we have no complete records on the height of all subjects studied, a statistical analysis of the available data $(n=14)$ failed to show a strong correlation between age and height (Spearman's range correlation coefficient rho $=-0.1757, P<0.60$ ). Ho et al. (1992) have demonstrated that only the size of Betz' cells in the frontal lobe was strongly correlated with height, but this was not so with hippocampal neurone size.

Therefore, in contrast to certain neocortical regions and brain stem nuclei (Konigsmark and Murphy 1970, 1972; Vijayashankar and Brody 1977 a, b), the neuronal 
Table 2. Neuron number calculated from Eqs. 1-6 to show hypothetical neurone loss from 20- to 85 -year-old and 100-year-old subjects

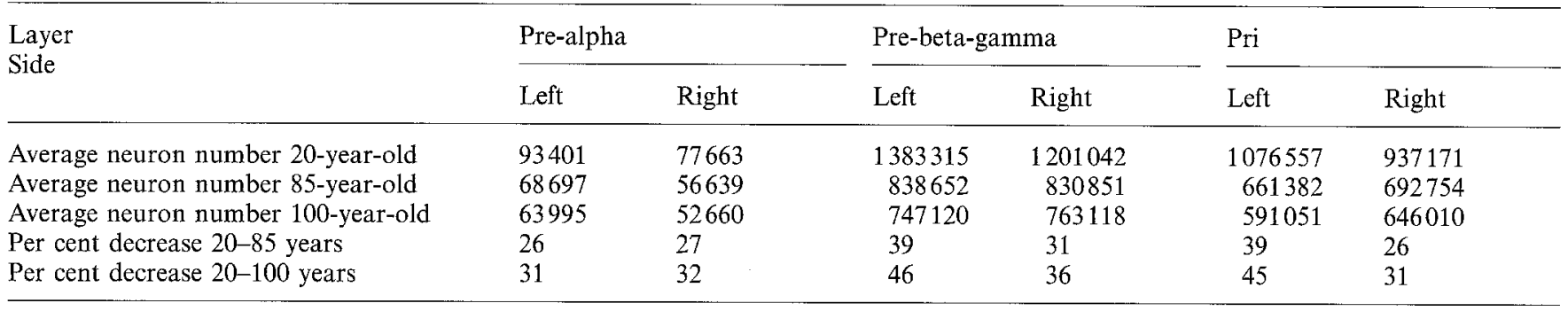

number of the entorhinal area probably exhibits an early nerve cell loss and thus offers an additional argument for the concept of regional differences in age-related neuronal changes (Brody 1976; Vijayashankar and Brody 1979; Wree et al. 1980; Haug et al. 1983; Eggers et al. 1984; Haug 1985; Terry et a1. 1987; West 1993b). The entorhinal area differs from the aforementioned brain regions by early onset as well as by continuous decline in neuronal number. The average nerve cell loss per decade can be calculated from the logarithmic equations (1) to (6). The calculated nerve cell loss and the percent decrease of age-related neurone numbers from 20- to 85year-old and 100-year-old human brains are summarized in Table 2. Interestingly, individual entorhinal layers exhibit different as well as asymmetric rates of age-related nerve cell loss. Neuronal loss is maximal in the left prilayers. These layers are known to receive subicular afferents (Witter et al. 1986). In a previous investigation West (1993) described a 52\% neuronal loss in this hippocampal field.

\section{Left-right asymmetry in nerve cell number and functional considerations}

Braak has clearly demonstrated the three-dimensional network of pre-alpha cell clusters in tangentially cut pigment preparations of the normal (Braak 1980) and early Alzheimer (Braak and Braak 1993) diseased entorhinal cortex. Hevner and Wong-Riley (1992) could replicate Braak's findings in cytochrome "oxidase-stained sections through the human entorhinal cortex. The authors found no precise bilateral symmetry of the cytochrome oxidase island pattern.

Our present results provide statistically significant data of a left-right asymmetry in pre-alpha cell number in 18 out of 22 cases studied $(82 \%)$. Quantitative asymmetries of the frontal (Galaburda 1980) and temporal lobes have been demonstrated in a variety of postmortem studies (Economo and Horn 1930; Geschwind and Levitsky 1968; Teszner et al. 1972; Wada et al. 1975; Chi et al. 1977; Kopp et al. 1977; Galaburda et al. 1978, 1987). The frequency of left-sided asymmetric brains has been shown to vary from $60 \%$ to $90 \%$. The size of the plana temporalia was mainly determined by planimetry, and the asymmetry expressed in planimetric units. A recent study by Steinmetz et al. (1990), comparing NMR measurements with post-mortem investigations, showed complex topographical bilateral relationships between the planum temporale and both ascending and descending Sylvian rami. The combined cortical surface areas failed to show significant left-right asymmetry.

In contrast to planimetric data, the calculation of total nerve cell numbers is free from histological artefacts or partial volume effects in neuroimaging. To date, there have been few investigations of quantitative left-right differences in neurone number in the human brain. Eidelberg and Galaburda (1982) delineated the thalamic lateralis posterior nucleus and found a higher nerve cell number in the left nucleus.

Asymmetries in the size of the human planum temporale and in the thalamic lateralis posterior nuclear cell number have both been related to asymmetries in language capabilities. The functional significance of the asymmetry in entorhinal pre-alpha cell number is difficult to assess. Case reports on bilateral destruction of structures of the mediobasal temporal lobe (Scoville and Milner 1957) and early affliction of the entorhinal region in Alzheimer's disease (Hyman et al. 1984; Braak and Braak 1991) suggest a memory function of the entorhinal region. Lesions of the entorhinal region in primates ( $\mathrm{Zo}-$ la-Morgan et al. 1993; Suzuki et al. 1993) point to major entorhinal contributions to memory consolidation. Hodological studies in the cat (Witter et al. 1986) have demonstrated that the entorhinal region (entorhinal and perirhinal area) consists of a framework of longitudinal, transverse, and vertical connections linking the hippocampal formation to neocortical fields. Superficial layers (I-III) are considered to represent a sensory gateway to the hippocampal formation. The deep layers (IVVI) receive hippocampal and subicular afferents and distribute these afferents to the perirhinal cortex as well as to widespread subcortical areas (Witter et al. 1986).

Age-related bilateral nerve cell loss in all entorhinal layers as described in the present study, can be assumed to disconnect this intricate neuronal network and finally result, in the absence of overt senile changes, in benign age-related forgetfulness. We have no psychometric data about the individuals investigated that could substantiate our assumption. We think that a correlation between memory scores and age-related entorhinal neuronal loss would be a promising field of investigation.

The functional significance of a left-sided increased pre-alpha cell number is difficult to assess. The numerical superiority of the pre-alpha cells over their contralateral mates is due to both increased average nerve cell density (left $11,475 \pm 1,909$ stellate cells $/ \mathrm{mm}^{3}$, right $10,882 \pm 1,782$ stellate cells $/ \mathrm{mm}^{3}$ ) and to the higher left- 
side average entorhinal volume (left entorhinal area 351 $\pm 81.3 \mathrm{~mm}^{3}$, right entorhinal area $342 \pm 76.8 \mathrm{~mm}^{3}$ ). Compared with the right section series, the left series frequently contained an additional section. The primate hippocampal formation differs from that of rodents, lagomorphs, and carnivores by considerably reduced commissural connections in primates (Amaral et al. 1984).

Electrophysiological studies of the hippocampal formation of epileptics (Wilson et al. 1991) corroborate and extend the findings in monkeys. In addition, combined neuropathological-neuropsychological investigations have demonstrated an impaired delayed-word recall in left-sided Ammon's horn sclerosis (Rausch and Babb 1993). Deficits in learning paired-word associates were associated with left hippocampal sclerosis, right hippocampal sclerosis, and left non-hippocampal sclerosis (Miller et al. 1993). Considering the vast amount of reciprocal entorhinal-association cortex connectivity, we think it feasible to speculate on speech capabilities and entorhinal neuronal number asymmetry.

In conclusion, we were struck by the immense individual cytoarchitectonic variability of the human entorhinal cortex, its individual variation in nerve cell number, and the asymmetry in pre-alpha cell number. In contrast to other brain regions, there is evidence for a continuous decrease in nerve cell numbers from the youngest to the oldest stages. This intricately laminated allocortex is probably involved in asymmetrically located higher mental capabilities including speech.

Acknowledgements. This study was supported by a grant from the Deutsche Forschungsgemeinschaft (He 1430/2-3 and 3-3). The authors thank Prof. Dr. H. Braak (University of Frankfurt) for valuable suggestions. The technical assistance of Mrs. E. Broschk and E. Gößmann, the photographic assistance of Mr. W. Nisch, the secretarial help of Mrs. R. Huttner and the statistical advice of Dr. I. Haubiz are gratefully acknowledged.

\section{References}

Amaral DG, Insausti R, Cowan WM (1984) The commissural connections of the monkey hippocampal formation. J Comp Neurol 224:307-336

Amaral DG, Insausti R, Cowan WM (1987) The entorhinal cortex of the monkey: I. Cytoarchitectonic organization. J Comp Neurol 264:326-355

Arnold SE, Hyman BT, Hoesen GW van, Damasio AR (1991) Some cytoarchitectural abnormalities of the entorhinal cortex in schizophrenia. Arch Gen Psychiatry 48:625-632

Bauchot R (1967) Les modifications du poid encéphalique au cours de la fixation. J Hirnforsch 6:253-283

Bauer M, Heinsen H, Berger K (1991) Nerve cell loss in allo- and neocortical regions in two cases of Huntington's disease. Clin Neuropathol 10:27

Beall MJ, Lewis DA (1992) Heterogeneity of layer II neurons in human entorhinal cortex. J Comp Neurol 321:241-266

Beck E (1940) Morphogenie der Hirnrinde. In: Bumke O, Foerster $\mathrm{O}$, Rüdin E, Spatz H (eds) Monographien aus dem Gesamtgebiete der Neurologie und Psychiatrie. Springer, Berlin, pp 1-167

Beckmann H, Heinsen H (1989) Letter to the editor. Morphometry of the entorhinal cortex. Biol Psychiatry 25:977-978

Beckmann H, Jakob H (1991) Prenatal disturbances of nerve cell migration in the entorhinal region: a common vulnerability factor in functional psychoses? J Neural Transm Gen Sect 84:155164
Blackstad TW (1956) Commissural connections of the hippocampal region in the rat. With special reference to their mode of termination. J Comp Neurol 105:417-537

Bogerts B, Falkai P (1989) Letters to the editor. Response. Biol Psychiatry 25:978-979

Braak H (1972) Zur Pigmentarchitektonik der Großhirnrinde des Menschen. I. Regio entorhinalis. Z Zellforsch Mikrosk Anat 127:407-438

Braak H (1980) Architectonics of the human telencephalic cortex. In: Braitenberg V (ed) Studies on brain function. Springer, Berlin Heidelberg New York, pp 1-147

Braak H, Braak E (1990) Cognitive impairment in Parkinson's disease: amyloid plaques, neurofibrillary tangles, and neuropil threads in the cerebral cortex. J Neural Transm Park Dis Dement Sect 2:45-57

Braak H, Braak E (1991) Neuropathological stageing of Alzheimerrelated changes. Acta Neuropathol 82:239-259

Braak H, Braak E (1992 a) Layer-specific allocortical destruction in Huntington's chorea (abstract). Clin Neuropathol 11:278

Braak H, Braak E (1992 b) Allocortical involvement in Huntington's disease. Neuropathol Appl Neurobiol 18:539-547

Braak H, Braak E (1993 a) Whole mount preparations displaying the progression of entorhinal neurofibrillary changes during initial stages of Alzheimer's disease (abstract). Clin Neuropathol 5:239

Braak H, Braak E (1993 b) Progression of entorhinal neurofibrillary changes during initial stages of Alzheimer's disease as seen in flattened whole mount preparations (abstract). Soc Neurosci Abstr 19:1475

Braak H, Braak E, Strenge H (1976) Gehören die Inselneurone der Regio entorhinalis zur Klasse der Pyramiden- oder der Sternzellen? Z Mikrosk Anat Forsch 90:1017-1031

Braendgaard H, Gundersen HJG (1986) The impact of recent stereological advances on quantitative studies of the nervous system. J Neurosci Methods 18:39-78

Braendgaard H, Evans SM, Howard CV, Gundersen HJ (1990) The total number of neurons in the human neocortex unbiasedly estimated using optical disectors. J Microsc 157:285-304

Brockhaus H (1940) Die Cyto- und Myeloarchitektonik des Cortex claustralis und des Claustrum beim Menschen. J Psychol Neurol 49:249-348

Brodmann K (1909) Vergleichende Lokalisationslehre der Großhirnrinde. Barth, Leipzig

Brody H (1955) Organization of the cerebral cortex. III. A study of aging in the human cerebral cortex. J Comp Neurol 102:511556

Brody $\mathrm{H}$ (1976) An examination of cerebral cortex and brainstem aging. In: Terry RD, Gershon S (eds) Neurobiology of aging (Aging, vol 3). Raven Press; New York, pp 177-181

Cajal SR (1972) Histologie du système nerveux de l'homme et des vertébrés. II. Consejo Superior de Investigaciones Cientificas, Madrid, pp 1-993

Chi JG, Dooling EC, Gilles FH (1977) Left-right asymmetries of the temporal speech areas of the human fetus. Arch Neurol 34:346348

Cruz-Orive LM (1983) Distribution-free estimation of sphere size distributions from slabs showing overprojection and truncation, with a review of previous methods. J Microse $131: 265-290$

Dekaban AS, Sadowsky D (1978) Changes in brain weights during the span of human life: relation of brain weights to body heights and body weights. Ann Neurol 4:345-356

Drüge H, Heinsen H, Heinsen YL (1986) Quantitative studies in ageing Chbb:THOM(Wistar) rats. II. Neuron numbers in lobules I, VIb $+\mathrm{c}$ and X. In: Kretschmann HJ (ed) Brain growth (Bibliotheca Anatomica, vol 28). Karger, Basel, pp 121-137

Duvernoy HM (1988) The human hippocampus. An atlas of applied anatomy. Bergmann, München, pp 1-166

Economo C von (1929) The cytoarchitectonics of the human cerebral cortex. Oxford University Press, London, pp 1-186

Economo $\mathrm{C}$ von, Horn $\mathrm{C}$ (1930) Über Windungsrelief, Maße und Rindenarchitektonik der Supratemporalfläche, ihre individuel- 
len und ihre Seitenunterschiede. Z Neurol Psychiatrie 130:678757

Eggers R, Haug H, Fischer D (1984) Preliminary report on macroscopic age changes in the human prosencephalon. A stereologic investigation. J Hirnforsch 25:129-139

Eidelberg D, Galaburda AM (1982) Symmetry and asymmetry in the human posterior thalamus. Arch Neurol 39:325-332

Falkai P, Bogerts B, Rozumek M (1988) Limbic pathology in schizophrenia: the entorhinal region - a morphometric study. Biol Psychiatry 24:515-520

Filimonoff IN (1947) A rational subdivision of the cerebral cortex. Arch Neurol Psychiatry 58:296-311

Flood DG, Coleman PD (1987) Neuron numbers and sizes in aging brain: comparison of human, monkey, and rodent data. Neurobiol Aging 9:453-463

Galaburda AM (1980) La région _ de Broca: observations anatomiques faites un siècle après la mort de son découvreur. Rev Neurol 136:609-616

Galaburda AM, Sanides F, Geschwind N (1978) Human brain: cytoarchitectonic left-right asymmetries in the temporal speech area. Arch Neurol 35:812-817

Galaburda AM, Corsiglia J, Rosen GD, Sherman GF (1987) Planum temporale asymmetry, reappraisal since Geschwind and Levitsky. Neuropsychologia 25:853-868

Geschwind N, Levitsky W (1968) Human brain: left-right asymmetries in temporal speech region. Science 161:186-187

Gundersen HJ (1986) Stereology of arbitrary particles. A review of unbiased number and size estimators and the presentation of some new ones. In memory of William R. Thompson. J Microse $143: 3-45$

Gundersen HJ, Jensen EB (1987) The efficiency of systematic sampling in stereology and its prediction. J Microsc 147:229-263

Haug H (1984) Der Einfluß der säkularen Acceleration auf das Hirngewicht des Menschen und dessen Änderung während der Alterung. Gegenb Morphol J 130:481-500

Haug $H$ (1985) Are neurons of the human cerebral cortex really lost during aging? A morphometric examination. In: Traber J, Gispen WH (eds) Senile dementia of the Alzheimer type. Springer, Berlin Heidelberg New York, pp 150-163

Haug H, Barmwater U, Eggers R, Fischer D, Kühl S, Sass N-L (1983) Anatomical changes in aging brain: morphometric analysis of the human prosencephalon. In: Cervós-Navarro J, Sarkander H-I (eds) Brain aging: neuropathology and neuropharmacology (Aging, vol 21). Raven Press, New York, pp $1-12$

Heckers S, Heinsen H, Heinsen Y, Beckmann H (1990) Morphometry of the parahippocampal gyrus in schizophrenics and controls. Some anatomical considerations. J Neural Transm Gen Sect $80: 151-155$

Heinsen H, Heinsen YL (1991) Serial thick, frozen, gallocyanin stained sections of human central nervous system. J Histotechnol 14:167-173

Heinsen H, Beckmann H, Heinsen YL, Gallyas F, Haas S, Scharff G (1990) Laminar neuropathology in Alzheimer's disease by a modified Gallyas impregnation. Psychiatr Res 29:463-465

Heinsen H, Bauer M, Ulmar G, Gangnus D, Jungkunz G (1992) The entorhinal region in Huntington's disease: a cytoarchitectonic and quantitative investigation in five cases (abstract). Clin Neuropathol 11:226

Hevner RF, Wong-Riley MTT (1992) Entorhinal cortex of the human, monkey, and rat: metabolic map as revealed by cytochrome oxidase. J Comp Neurol 326:451-469

Hirano A, Zimmerman HM (1962) Alzheimer's neurofibrillary changes. A topographic study. Arch Neurol 7:227-242

Ho K-C, Roessmann U, Straumfjord JV, Monroe G (1980a) Analysis of brain weight. I. Adult brain weight in relation to sex, race, and age. Arch Pathol Lab Med 104:635-639

Ho K-C, Roessmann U, Straumfjord JV, Monroe G (1980b) Analysis of brain weight. II. Adult brain weight in relation to body height, weight, and surface area. Arch Pathol Lab Med 104:640645
Ho KC, Gwozdz JT, Hause LL, Antuono PG (1992) Correlation of neuronal cell body size in motor cortex and hippocampus with body height, body weight, and axonal length. Int $\mathbf{J}$ Neurosci $65: 147-153$

Hoesen GW van (1982) The parahippocampal gyrus - new observations regarding its cortical connections in the monkey. Trends Neurosci 5:345-350

Hoesen GW van, Pandya DN (1975a) Some connections of the entorhinal (area 28) and perirhinal (area 35) cortices of the rhesus monkey. I. Temporal lobe afferents. Brain Res 95:1-24

Hoesen GW van, Pandya DN (1975b) Some connections of the entorhinal (area 28) and perirhinal (area 35) cortices of the rhesus monkey. III. Efferent connections. Brain Res 95:39-59

Hoesen GW van, Pandya DN, Butters N (1975) Some connections of the entorhinal (area 28) and perirhinal (area 35) cortices of the rhesus monkey. II. Frontal lobe afferents. Brain Res 95:25-38

Hooper MW, Vogel S (1976) The limbic system in Alzheimer's disease. Am J Pathol 85:1-20

Hyman BT, Hoesen GW van, Damasio AR, Barnes CL (1984) Alzheimer's disease: cell-specific pathology isolates the hippocampal formation. Science 225:1168-1170

Hyman BT, Hoesen GW van, Damasio AR (1990) Memory-related neural systems in Alzheimer's disease: an anatomic study. Neurology 40:1721-1730

Jakob H (1979) Die Picksche Krankheit. Eine neuropathologischanatomisch-klinische Studie. In: Hippius $\mathrm{H}$, Janzarik W, Müller $\mathrm{C}$ (eds) Monographien aus dem Gesamtgebiete der Psychiatrie. Psychiatry Series. Springer, Berlin Heidelberg New York, pp $1-110$

Jakob H, Beckmann H (1986) Prenatal developmental disturbances in the limbic allocortex in schizophrenics. J Neural Transm $65: 303-326$

Kemper TL (1978) Senile dementia: a focal disease of the temporal lobe. In: Nandy K (ed) Senile dementia. A biomedical approach. Elsevier/North Holland, Amsterdam New York, pp 5-113

Köhler C (1988) Intrinsic connections of the retrohippocampal region in the rat brain. III. The lateral entorhinal area. J Comp Neurol 271:208:228

Konigsmark BW, Murphy EA (1970) Neuronal populations in the human brain. Nature 228:1335-1336

Konigsmark BW, Murphy EA (1972) Volume of the ventral cochlear nucleus in man: its relationship to neuronal population and age. J Neuropathol Exp Neurol 31:304-316

Kopp N, Michel F, Carrier H, Biron A, Duvillard P (1977) Étude de certaines asymétries hémispherique du cerveau humain.J Neurol Sci 34:349-363

Kretschmann HJ, Schleicher A, Wingert F, Zilles K, Loeblich HJ (1979) Human brain growth in the 19th and 20th century. J Neurol Sci 40:169-188

Kretschmann HJ, Kammradt G, Krauthausen I, Sauer B, Wingert F (1986) Brain growth in man. In: Kretschmann HJ (ed) Brain growth. (Bibliotheca Anatomica, vol 28) Karger, Basel, pp 1-26

Krieg WJS (1946) Connections of the cerebral cortex. I. The albino rat. B. Structure of the cortical areas. J Comp Neurol 84:277323

Lorente de Nó R (1933) Studies on the structure of the cerebral cortex. I. The area entorhinalis. J Psychol Neurol 45:381-438

McLardy T (1970) Memory function in hippocampal gyri but not in hippocampi. Int J Neurosci 1:113-118

Miller AKH, Corsellis JAN (1977) Evidence for a secular increase in human brain weight during the past century. Ann Hum Biol $4: 253-257$

Miller AKH, Alston RL, Corsellis JAN (1980) Variation with age in the volumes of grey and white matter in the cerebral hemispheres of man: measurement with an image analyser. Neuropathol Appl Neurobiol 6:119-132

Miller LA, Munoz DG, Finmore M (1993) Hippocampal sclerosis and human memory. Arch Neurol 50:391-394

Pakkenberg B, Evans SM, Moller A, Braendgaard H, Gundersen HJG (1989) Total number of neurons in human neocortex relat- 
ed to age and sex estimated by way of optical disectors. Acta Stereologica 8:251-256

Rausch R, Babb TL (1993) Hippocampal neuron loss and memory scores before and after temporal lobe surgery for epilepsy. Arch Neurol 50:812-817

Regeur L, Pakkenberg B (1989) Optimizing sampling designs for volume measurements of components of human brain using a stereological method. J Microse 155:113-121

Room P, Groenewegen HJ (1986) Connections of the parahippocampal cortex. I. Cortical afferents. J Comp Neurol 251:415-450

Rose M (1926) Der Allocortex bei Tier und Mensch. J Psychol Neurol 34:1-111

Rose M (1927) Die sog. Riechrinde beim Menschen und beim Affen. II. Teil des "Allocortex bei Tier und Mensch". J Psychol Neurol $34: 262-401$

Rose S (1927) Vergleichende Messungen im Allocortex bei Tier und Mensch. J Psychol Neurol 34:250-255

Rosene DL, Hoesen GW van (1987) The hippocampal formation of the primate brain: a review of some comparative aspects of cytoarchitecture and connections. In: Jones EG, Peters A (eds) Further aspects of cortical function, including hippocampus. (Cerebral cortex, vol 6) Plenum Press, New York, pp 345-456

Rosene DL, Roy NJ, Davis BJ (1986) A cryoprotection method that facilitates cutting frozen sections of whole monkey brains for histological and histochemical processing without freezing artifacts. J Histochem Cytochem 34:1301-1315

Röthig W (1974) Korrelation zwischen Gesamthirn- und Kleinhirngewicht des Menschen im Laufe der Ontogenese. J Hirnforsch 15:203-209

Sanides F (1969) Comparative architectonics of the neocortex of mammals and their evolutionary interpretation. Ann NY Acad Sci 167:404-423

Scholz W (1957) Die nicht zur Erweichung führenden unvollständigen Gewebsnekrosen (Elektive Parenchymnekrose). In: Scholz W (ed) Handbuch der speziellen pathologischen Anatomie und Histologie, vol XIII. Nervensystem, part 1/B, Springer, Berlin Heidelberg New York, pp 1284-1325

Scoville WB, Milner B (1957) Loss of recent memory after bilateral hippocampal lesions. J Neurol Neurosurg Psychiatry 20:11-21

Sgonina K (1937) Zur vergleichenden Anatomie der Entorhinalund Präsubikularregion. J Psychol Neurol 48:56-163

Smith RW, White LE (1964) The fiberarchitectonics of the cat hippocampal formation. J Comp Neurol 11:27

Spann W, Dustmann HO (1965) Das menschliche Hirngewicht und seine Abhängigkeit von Lebensalter, Körperlänge, Todesursache und Beruf. Dtsch Z Ges Gericht Med 56:299-317

Steinmetz H, Rademacher J, Jäncke L, Huang Y, Thron A, Zilles K (1990) Total surface of temporoparietal intrasylvian cortex: diverging left-right asymmetries. Brain Lang 39:357-372

Stephan H (1960) Methodische Studien über den quantitativen Vergleich architektonischer Struktureinheiten des Gehirns. Z Wiss Zool 164:143-172

Stephan H (1975) Allocortex. In: Bargmann W (ed) Handbuch der mikroskopischen Anatomie des Menschen, vol 4. Nervensystem, part 9. Springer, Berlin Heidelberg New York, pp 1-998
Suzuki WA, Zola-Morgan S, Squire LR, Amaral DG (1993) Lesions of the perirhinal and parahippocampal cortices in the monkey produce long-lasting memory impairment in the visual and tactual modalities. J Neurosci 13:2430-2451

Terry RD, DeTeresa R, Hansen LA (1987) Neocortical cell counts in normal human adult aging. Ann Neurol 21:530-539

Teszner D, Tzavaras A, Gruner J, Hecaen H (1972) L'asymétrie droite-gauche du planum temporale: à propos de l'étude anatomique de 100 cerveaux. Rev Neurol 126:444-449

Trillo L, Gonzalo LM (1992) Ageing of the human entorhinal cortex and subicular complex. Histol Histopathol 7:17-22

Vaz Ferreira A (1951) The cortical areas of the albino rat studied by silver impregnation. J Comp Neurol 95:177-243

Vijayashankar N, Brody H (1977a) Aging in the human brain. A study of the nucleus of the trochlear nerve. Acta Anat 99:169172

Vijayashankar N, Brody H (1977b) A study of aging in the human abducens nucleus. J Comp Neurol 173:433-438

Vijayashankar N, Brody H (1979) A quantitative study of the pigmented neurons in the nuclei locus coeruleus and subcoeruleus in man as related to aging. J Neuropathol Exp Neurol 38:490. 497

Wada J, Clarke R, Hamm A (1975) Cerebral hemispheric asymmetry in humans. Cortical speech zones in 100 adult and 100 infant brains. Arch Neurol 32:239-246

Weibel ER (1979) Stereological methods, vol 1. Academic Press, London New York, pp 1-415

West MJ (1993a) New stereological methods for counting neurons. Neurobiol Aging 14:275-285

West MJ (1993b) Regionally specific loss of neurons in the aging human hippocampus. Neurobiol Aging 14:287-293

West MJ, Gundersen HJG (1990) Unbiased stereological estimation of the number of neurons in the human hippocampus. J Comp Neurol 296:1-22

Wilson CL, Isokawa M, Babb TL, Crandall PH, Levesque MF, Engel J Jr. (1991) Functional connections in the human temporal lobe. II. Evidence for a loss of functional linkage between contralateral limbic structures. Exp Brain Res 85:174-187

Witter MP, Room P, Groenewegen HJ, Lohman AMH (1986) Connections of the parahippocampal cortex in the cat. V. Intrinsic connections; comments on input/output connections with the hippocampus. J Comp Neurol 252:78-94

Witter MP, Groenewegen HJ, Lopes da Silva FH, Lohman AHM (1989) Functional organization of the extrinsic and intrinsic circuitry of the parahippocampal region. Prog Neurobiol 33:161253

Wree A, Braak H, Schleicher A, Zilles K (1980) Biomathematical analysis of the neuronal loss in the aging human brain of both sexes, demonstrated in pigment preparations of the pars cerebellaris loci coerulei. Anat Embryol 160:105-119

Zola-Morgan S, Squire LR, Clower RP, Rempel NL (1993) Damage to the perirhinal cortex exacerbates memory impairment following lesions to the hippocampal formation. J Neurosci 13:251265

Zunino G (1909) Die myeloarchitektonische Differenzierung der Großhirnrinde beim Kaninchen (Lepus cuniculus). J Psychol Neurol 14:38-70 